\title{
The Characteristics Of Users Derivative Company Towards The Company's Value
}

\author{
Margarita Ekadjaja, Henny, and Agustin Ekadjaja \\ Fakultas Ekonomi Universitas Tarumanagara \\ Email:margarita@fe.untar.ac.id,henny@fe.untar.ac.id,agustine@fe.untar.ac.id
}

\begin{abstract}
The use of derivative instruments can be used to control financial risk to be able to drive an increase in company value. The contribution of this study is to seek the relationship between variables that can increase company value, then increasing the value of the company can achieve the company's goal of increasing shareholder prosperity. The population in this study are all companies listed in the Sharia Stock Index on the Indonesia Stock Exchange in 2014-2016. Multiple linear regression analysis is used to test the hypothesis. The result of the test showed that the Return On Asset and firm size variables have a significant positive effect on the firm value of derivative users. While capital expenditure and dividend yield showed that there is no significant effect on firm value and the leverage variable showed a significant negative effect on firm value.
\end{abstract}

Keywords: return on asset, leverage, capital expenditure, firm size, the dividend yield.

\section{INTRODUCTION}

In the current era of globalization, business competition related to investment and funding is very complex. Alternative financial instruments are increasingly developing in line with the development of investment and funding. Along with more profitable offers, investors begin to move their investment portfolios to other companies. The key to a company to maintain its investors, both shareholders, debt holders, and other stakeholders is by constantly creating and realizing the value of the company.

The role of the company's value is very large because the value of the company is a consideration of the level of success of the company (Shapiro, 2013). The high value of the firm will lead to market confidence that not only trusts the company's current performance, but also the future prospects of the company. This proves that the value of the firm is very important for a company.

Derivatives are very important financial instruments, for the economy or business. According to (Putro, 2012), derivatives are financial contracts where the value comes from the underlying assets. This means that derivative financial instruments are financial instruments whose value depends or is derived from the underlying assets. Derivatives are used as financial engineering tools. This engineering is known as hedging which is a way of managing risk. But derivatives can also be intended for profit. Basically, almost all company activities are related to the international market. Therefore, the company's cash flow is affected by changes in exchange rates. In companies that are international in scale, derivative activities in the form of hedging are very necessary. Hedging in question is a reserve hedge in the form of foreign exchange currency against the risks that occur as a result of changes in a country's foreign exchange rates. 


\section{THEORITICAL REVIEW}

According to (García-Feijoo et al., 2015), hedging activities that are generally used by companies include:

1) Hedging with investments in the money market. Hedging through investment in the money market is done by buying short-term investment instruments that aim to protect the value of debt or receivables that will be realized in the future.

2) Hedging by making a futures contract futures contract is an agreement to settle a currency exchange transaction on the date and number of transactions in accordance with the agreement. Futures contracts are used by companies in hedging activities on relatively small transactions.

3) Hedging by making forward contracts. A forward contract is an agreement to settle an exchange transaction for foreign currency in the future, as the forward contracts are binding and irrevocable.

4) Hedging by making an option contract. The option contract is the right purchased in the purchase or sale of currency in the future according to the price of the contract and executed on the agreed date. Hedging through making an option contract is flexible, where the contract does not need to be executed if in the future the value of the contract is not profitable.

According to (Eiteman et al., 2012), the companies that use derivative instruments in the context of hedging can be done through the making of contracts that the execution of the contract will be carried out according to a mutual agreement. The difference between hedging through making an option contract and hedging through the making of a futures contract (forward) is that in an option contract if the contract value is not profitable then the contract buyer has no obligation to execute the contract but still has to pay the premium. Hedging through the making of a futures contract (forward), the contract buyer has an obligation to execute a signed contract, whether the contract value is profitable or not, but the contract buyer does not have a premium. The equation between hedging through the making of option contracts and hedging through the making of futures contracts (forward) is both option and futures (forward) derivative instruments having exchanges and having sales units in the form of the lot.

The use of derivative user policies has increased for the past few years in developed countries, but empirical studies of the determinants of hedging policy for derivative users are still limited and require more extensive research, especially in developing countries (Khediri, 2010). (Bartram et al., 2012) conducted research related to the problem of corporate value in derivative user companies by using variables firm size, book-to-market ratio, and leverage together. The result of their research showed that firm size and bookto-market book play an important role in explaining the yield of shares on the value of the firm. (Nurqinanty, 2018) suggested that the use of derivatives by companies has a positive impact on the market value of the company with the variables used include: SIZE, LEV, and ROA. According to (Kartini and Hasridha, 2014) stated that large companies often use hedging rather than small companies in controlling the value of the company. (Nandita, 2018) found a negative influence between leverage and company value on companies using derivative instruments.

(Aaj et al., 2016) argued that companies that use hedging have the opportunity to invest in assets. Whereas (Boumosleh and Raad, 2012) found a positive relationship 
between CAPEX and company value and the effect of its significance was not too strong. According to (Setiawan and Kartika, 2013), the higher the dividend yield, the lower the possible effect on firm value.

This study used a sample of companies listed on the Sharia Stock Index on the Indonesia Stock Exchange in 2014-2016, where companies are highly productive and use derivatives in protecting their products and assets from foreign exchange fluctuations. (Fitriasari, 2011) illustrated that companies that actively carry out export-import transactions are companies that tend to have greater foreign exchange exposures, and in the financial statements will be recorded in foreign currency assets or liabilities.

This study examines whether the Return on Assets (ROA), firm size (SIZE), leverage (LEV), capital expenditure (CAPEX), and dividend yield variables have a positive and significant effect on derivative user firms on firm value. Thus the formulation of the problem in this study is: (1) What is the influence of Return on Assets (ROA) of a user of a derivative company on company's value?; (2)What is the effect of company size (SIZE) of the derivative user company on company's value?; (3) What is the effect of leverage (LEV) on user derivative companies on company's value?; (4) What is the effect of the company's derivative capital expenditure (CAPEX) on the company's value?; (5) How is the effect of dividend yield on the user of the derivative company on company's value?

Based on empirical phenomena and research gap from the result of previous research, the problems in this study is to investigate how the influence of Return on Assets, leverage, capital expenditure, company's size, and dividend yield variables on derivative user companies on company's value. The expected result of this study is used to analyze the influence between these variables and the value of the company.

\section{METHODOLOGY}

The design of this study uses a quantitative approach, in which the data obtained is secondary data, hence, the purpose of the study is to analyze the characteristics of companies using derivatives with the variable Return On Assets (ROA), SIZE as a variable to measure firm size, LEV as a variable to measure company leverage which is proxied by the debt ratio, CAPEX as a variable to measure capital expenditure, and dividend yield (DIV) to the value of the company. The initial stage in processing data starts from descriptive statistical analysis up to the result of the hypothesis, and the conclusion can be drawn.

Sources of data come from financial data of companies listed on the Sharia Stock Index on the Indonesia Stock Exchange for the 2014-2016 period, with indicators of companies being derivative users and having complete financial statements from 20142016 that are useful for measuring variables ROA, SIZE, LEV, CAPEX, DIV, and company value.

This study uses Tobin $Q$ as a variable of company value. The dependent variable in this study is the firm value that is proxied by the Tobin $Q$ value. The measurement of firm value using Tobin $Q$ is done by looking at the value of the intangible assets and tangible assets of the company. If the value of Tobin $Q$ is zero to one, this indicated that the value of the company is low and the cost of replacing the assets of the company is greater than the market value of the company (Willim, 2015). This means that the market assesses less to the company. On the other hands, if the value of Tobin $Q$ in the company is high (more 
than one) it is indicated that the value of the company is greater than the value of the assets of the listed company. This means that there are still several company assets that are not measured or recorded.

Company value can be calculated using the Tobin $\mathrm{Q}$ ratio with the following formula: (Willim, 2015)

$$
\mathrm{Q}=\frac{\text { (Stock market price } \mathrm{x} \text { number of shares outstanding })+ \text { book value of debt }}{\text { Book Value of Total Assets }}
$$

The independent variables in this study are Return on assets, Firm size, Leverage, capital expenditure, and dividend yield.

Return on Assets (ROA) is one of the financial ratios used to assess the level of profitability of a company. According to Bolek (2014), ROA is a ratio used to measure the net profit obtained from the use of assets.

The following formula for calculating the ROA of a company:

$$
\text { ROA }=\text { Net profit: Total Asset }
$$

According to (Du and Girma, 2012), the size of the company is seen as a large company and small company. In reporting on its financial condition, the company needs to apply a prudent and more transparent system so that the company has a higher quality of earnings which causes an increase in the value of the company. (Sadiah and Priyadi, 2015) stated that firm size is measured by the logarithm of total assets. The result of the size of the company is obtained if the total asset logarithm calculation is large.

The formula for calculating the size of the company:

$$
\mathrm{SIZE}=\log \text { Total Asset }
$$

The result of (Putro and Chabachib's, 2012) showed that there is a significant and positive relationship between the leverage of the company's hedging activities. This is the opposite of the result of (Sprcic and Sevic, 2012) which result in the leverage ratio do not affect the company's hedging activities. Moreover, the result of the research of Tai, Lai, and Lin (2014) stated that there is a unidirectional (positive) relationship between liquidity and the company's decision to engage in hedging activities, but (Arnold et al., 2014) stated the relationship between liquidity and corporate decisions to hedge is the opposite (negative).

Leverage is used to explain the company's ability to use assets and sources of funds to increase the returns to their owners (Wulansari, 2013). (Watson, 2013) explained that leverage proportion by describing the proportion between total liabilities and total assets held. Mathematically leverage (LEV) can be formulated as follows:

$$
L E V=\text { Total long term debt }: \text { Total Asset }
$$

Cassidy et al., (2012) explained that capital expenditure or expenditure is expenditure to improve operating efficiency, increase productive capacity, or extend the useful life of 
fixed assets are generally quite large (material) and the occurrence of non-frequency (sudden).

The ratio of capital expenditure to sales is used to measure CAPEX which is a proxy for investment opportunities. (McCown and Shaw, 2017) argued that companies that do hedges are preferred because they have investment opportunities.

Mathematically CAPEX can be formulated as follows:

\section{CAPEX $=$ Total capital expenditure $:$ Total sales}

According to (Setiawan T., 2017), dividends are compensation received by shareholders, in addition to capital gains. Dividends are part of the profits available to ordinary shareholders. The level of profit provided by the company is called dividend yield. Therefore it can be formulated :

\section{Dividend yield $=$ dividend: stock market price}

(Servaes and Tamayo, 2013) stated that company value is obtained by discounting the company's cash flow estimates. According to (Aaj et al., 2016) company value is an investor's perception which is often associated with stock prices. This means that by understanding the value of the company, company management is explained that the price of an asset and fundamental factors, which affect the price of the asset, in which the company's main goal is to maximize the value of the company.

(Eiteman et al., 2012) defined a derivative instrument as an agreement between two parties (buyer and seller) in which the contract has an agreement in accordance with the agreement, but the realization is on a certain date in the future. The derivatives market players are concentrated in risk management, such as exchange risk, the risk of commodity price movements, the risk of changes in interest rates, risk of changes in stock prices. One of the uses of derivative instruments is the use of futures contracts. The use of derivative instruments also allows various participants to protect the risk of loss from the value of their assets because the decline in value can be determined only to the desired or planned tolerance limit.

The Investors (hedgers) can diversify their financial risks using derivative instruments. When it is in line with expectations, the participants maintain the risk to get more results, and vice versa. This is important for multinational companies in carrying out their business activities. Multinational companies must hedge to obtain protection from interest rate risk and the risk of exchange rate changes. The use of derivative instruments allows multinational companies to avoid the risk of fluctuating prices so they can focus more on the company's main business activities.

The research model is focused on five variables, namely: ROA, SIZE, LEV, CAPEX, and dividend yield. The formation of this pattern as a model for controlling agency conflict so that managers' behavior and decisions will have a positive impact on improving Tobin's Q. The identification of the effect of using derivatives ROA, SIZE, LEV, CAPEX with firm value is illustrated in figure one about the research model. 
Figure 1. Research Model

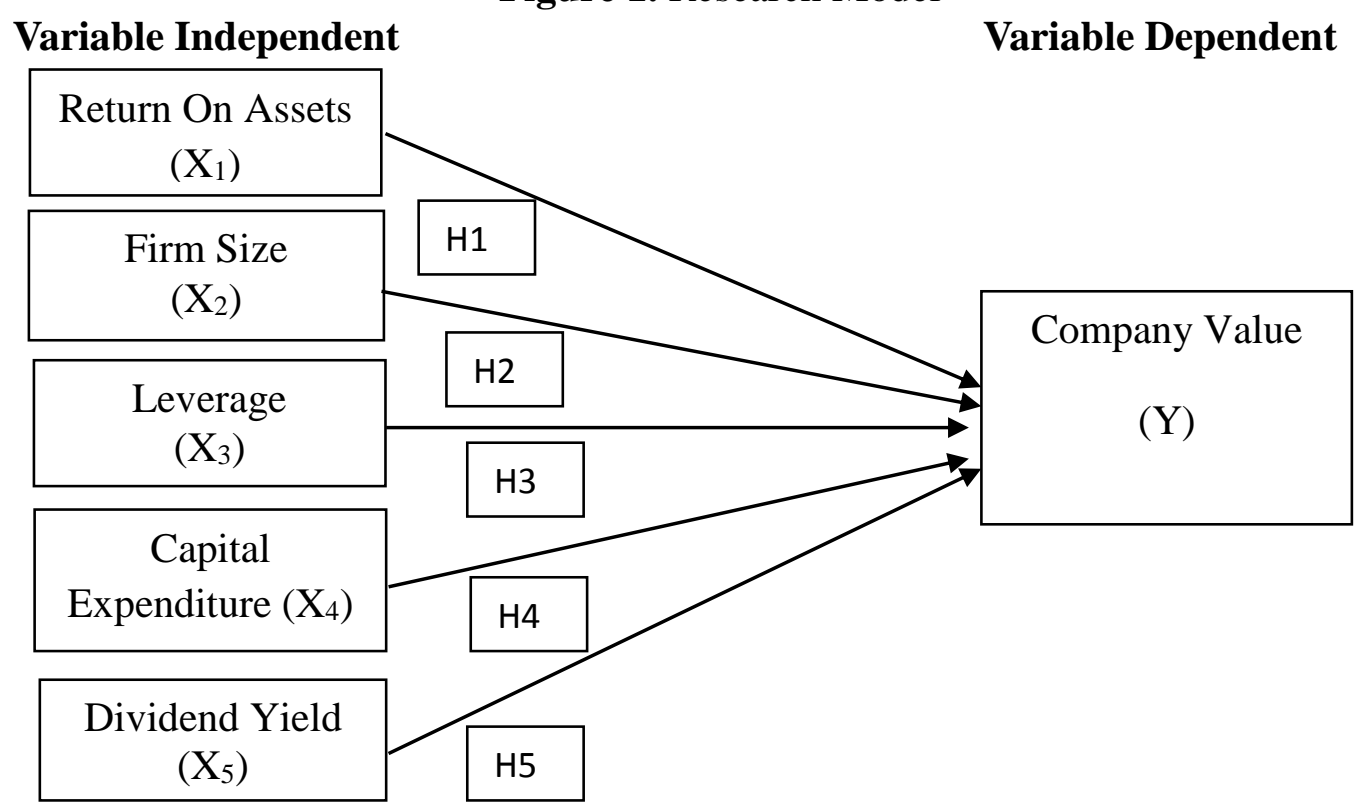

Source: (Result of data analysis, 2019)

Table 1. Previous Researcher

\begin{tabular}{|c|c|c|c|c|}
\hline $\begin{array}{l}\text { Researc } \\
\text { hers }\end{array}$ & $\begin{array}{l}\text { The title of } \\
\text { Research }\end{array}$ & $\begin{array}{l}\text { Variable } \\
\text { Independent }\end{array}$ & $\begin{array}{l}\text { Variable } \\
\text { Control }\end{array}$ & Result \\
\hline $\begin{array}{l}\text { (Fay, } \\
2017)\end{array}$ & $\begin{array}{l}\text { Factors } \\
\text { Affecting } \\
\text { Hedging } \\
\text { Activities with } \\
\text { Foreign } \\
\text { Exchange } \\
\text { Derivative } \\
\text { Instruments }\end{array}$ & $\begin{array}{l}\text { 1. Leverage } \\
\text { 2. Liquidity } \\
\text { 3. Firm Size } \\
\text { 4. Financial } \\
\text { Distress } \\
\text { 5. Firm Value } \\
\text { 6. Growth } \\
\text { Opportunity }\end{array}$ & & $\begin{array}{l}\text { 1. (+)Significant } \\
\text { 2. (-)Significant } \\
\text { 3. (+)Significant } \\
\text { 4. (+)Significant } \\
\text { 5. (+)Not } \\
\text { Significant } \\
\text { 6. (+)Not } \\
\quad \text { Significant }\end{array}$ \\
\hline $\begin{array}{l}\text { (Lau, } \\
\text { 2016) }\end{array}$ & $\begin{array}{l}\text { How Corporate } \\
\text { Derivatives } \\
\text { Use Impact } \\
\text { Firm } \\
\text { Performance }\end{array}$ & $\begin{array}{l}\text { 1. Derivatives } \\
\text { 2. Size } \\
\text { 3. Dividend } \\
\text { 4. Leverage } \\
\text { 5. Growth } \\
\text { 6. ROA } \\
\text { 7. Industry } \\
\text { 8. Year }\end{array}$ & & $\begin{array}{l}\text { 1.(-)Significant } \\
\text { 2.(+)Significant } \\
\text { 3. (+)Significant } \\
\text { 4. (-)Significant } \\
\text { 5. (+)Significant } \\
\text { 6. (+)Significant } \\
\text { 7. (-)Significant } \\
\text { 8. (-)Significant }\end{array}$ \\
\hline $\begin{array}{l}\text { (Ambar } \\
\text { wati and } \\
\text { Hikmah, } \\
\text { 2014) }\end{array}$ & $\begin{array}{l}\text { Relationship of } \\
\text { Ownership } \\
\text { Structure, Debt } \\
\text { Levels, } \\
\text { Dividends, and } \\
\text { Company }\end{array}$ & $\begin{array}{l}\text { 1. Debt Level } \\
\text { 2. Managerial } \\
\text { Ownership } \\
\text { 3. Dividends }\end{array}$ & & $\begin{array}{l}\text { 1. (-)Significant } \\
\text { 2. (+)Significant } \\
\text { 3. (-)Significant }\end{array}$ \\
\hline
\end{tabular}




\section{Values in \\ Reducing \\ Agency \\ Conflict in \\ Indonesia}

\begin{tabular}{|c|c|c|c|c|}
\hline $\begin{array}{l}\text { (Zeng, } \\
2014 \text { ) }\end{array}$ & $\begin{array}{l}\text { Derivative } \\
\text { financial } \\
\text { instruments, tax } \\
\text { aggressiveness, } \\
\text { and firm } \\
\text { market value. }\end{array}$ & $\begin{array}{l}\text { 1. Dividend } \\
\text { Yield } \\
\text { 2. Tax }\end{array}$ & & $\begin{array}{l}\text { 1. (+)Significant } \\
\text { 2. (-) Not } \\
\quad \text { Significant }\end{array}$ \\
\hline $\begin{array}{l}\text { (Obrado } \\
\text { vich dan } \\
\text { Gill, } \\
2013)\end{array}$ & $\begin{array}{l}\text { The Impact of } \\
\text { Corporate } \\
\text { Governance } \\
\text { and Financial } \\
\text { Leverage on } \\
\text { the Value of } \\
\text { American } \\
\text { Firms }\end{array}$ & $\begin{array}{l}\text { 1. CEO } \\
\text { Duality } \\
\text { 2. Board Size } \\
\text { 3. Audit } \\
\text { Committee } \\
\text { 4. Financial } \\
\text { Leverage }\end{array}$ & $\begin{array}{l}\text { a. Firm Size } \\
\text { b. ROA } \\
\text { c. Insider } \\
\text { Holdings }\end{array}$ & $\begin{array}{l}\text { 1. (+) Significant } \\
\text { 2. (-) Significant } \\
\text { 3. (+) Significan } \\
\text { 4. (+) Significant } \\
\text { a. (+) Significant } \\
\text { b. (+) Significant } \\
\text { c. (+) Significant }\end{array}$ \\
\hline $\begin{array}{l}\text { (Cassidy } \\
\text { et al., } \\
\text { 2012) }\end{array}$ & $\begin{array}{l}\text { Derivative } \\
\text { usage and firm } \\
\text { value: The } \\
\text { influence of } \\
\text { agency cost and } \\
\text { monitoring } \\
\text { problems }\end{array}$ & $\begin{array}{l}\text { 1. Industry } \\
\text { segment } \\
\text { 2. Geographic } \\
\text { segment } \\
\text { 3. Div dummy } \\
\text { 4. Operating } \\
\text { income to } \\
\text { sell } \\
\text { 5. Capital exp. } \\
\text { To sell } \\
\text { 6. Log total } \\
\text { asset } \\
\text { 7. Leverage } \\
\text { 8. Derivative } \\
\text { usage } \\
\text { indicator }\end{array}$ & & $\begin{array}{l}\text { 1. (-) Significant } \\
\text { 2. (+) Significant } \\
\text { 3. (-) Significant } \\
\text { 4. (-) Not } \\
\text { Significant } \\
\text { 5. (+)Significant } \\
\text { 6. (+)Significant } \\
\text { 7. (-)Significant } \\
\text { 8. (-)Not } \\
\text { Significant }\end{array}$ \\
\hline
\end{tabular}

Source : (Result of data analysis, 2019)

Based on table one about previous research, (Lau, 2016) and (Obradovich and Gill, 2013) can be described that the result of the research which the financial markets prefer companies that provide large rewards or profits with high corporate value. Companies that use derivatives tend to have control over the value of the company to benefit the financial market. It can be concluded that if the company's return on asset (ROA) is high, it is possible that the value of the company will be closed.

Based on the above statement, the hypothesis that can show the effect of Return on Assets on Company Values is: 
H1: Return On Assets has a positive effect on Company Value.

(Lau, 2016), (Ambarwati and Hikmah, 2014), and (Obradovich and Gill, 2013) argued that larger companies prefer to use derivatives to control high-cost prices, this can control the value of the company when using derivatives. The higher the firm size, the higher the value of the company. Based on the research and analysis above, the hypothesis that can show the effect of Firm Size on Firm Value is:

H2: Firm Size has a positive effect on Company Value.

(Lau, 2016) argued that the company's capital structure is closely related to the value of the company, because the higher the leverage, the higher the interest expense, so the value of the company will decrease after deducting interest and tax expenses. Based on the research and analysis above, the hypothesis that can show the influence of leverage on the value of the company is:

H3: Leverage has a negative effect on Company Value.

(Cassidy et al., 2012) stated that the opportunity to invest in a company is indicated by the existence of capital expenditure where the company that does the hedge is more willing to invest in fixed assets. The higher the investment made in capital expenditure, the higher the value of the company.

Based on the research and analysis above, the hypothesis that can show the effect of Capital Expenditure on Firm Value is:

H4: Capital Expenditure has a positive effect on Company Value.

(Zeng, 2014) indicated that if a company does a hedge or derivative for a project, this is because the company has limited access to financial markets. Therefore, companies that pay high dividends will reduce the value of the company due to the large dividends paid to ordinary shareholders in that year. Based on the research and analysis above, the hypothesis that can show the effect of Yield Dividend on Company Value is:

H5: Dividend Yield has a negative effect on Company Value.

\section{RESULT AND DISCUSSION}

This research used panel data and quantitative methods. The sample selection uses a purposive sampling method with criteria: (1) The data is taken from the financial statements of companies listed on the Sharia Stock Index on the Indonesia Stock Exchange; (2) The company must carry out derivative activities for three consecutive years. Based on these criteria, thirty data were identified to be observed.

Testing the classical multicollinearity assumption using the Pearson test showed the correlation matrix value is less than 0.80 ; however, by comparing the value of 0.80 it is identified that there is no multicollinearity between the three independent variables.

The overall results in table two about the correlation matrix, as follows: 
Table 2. Correlation Matrix

\begin{tabular}{lrrrrrr}
\hline & \multicolumn{1}{l}{ ROA } & \multicolumn{1}{l}{ LEV } & \multicolumn{1}{l}{ DIV } & \multicolumn{1}{l}{ SIZE } & \multicolumn{1}{l}{ CAPEX } & \multicolumn{1}{l}{ Q } \\
\hline \hline ROA & 1.000000 & 0.827391 & -0.550121 & 0.087369 & 0.509188 & 0.239578 \\
LEV & 0.827391 & 1.000000 & -0.506505 & 0.213509 & 0.440080 & 0.076644 \\
DIV & -0.550121 & -0.506505 & 1.000000 & 0.084226 & -0.209472 & -0.166552 \\
SIZE & 0.087369 & 0.213509 & 0.084226 & 1.000000 & 0.159364 & -0.236033 \\
CAPEX & 0.509188 & 0.440080 & -0.209472 & 0.159364 & 1.000000 & 0.007135 \\
Q & 0.239578 & 0.076644 & -0.166552 & -0.236033 & 0.007135 & 1.000000 \\
\hline
\end{tabular}

Source : (Result of data analysis, 2019)

Based on the table of two correlation matrices, the highest correlation value between capital expenditure with Leverage, in which the result of the company expenditure in increased corporate debt. The positive direction between the two variables showed that the higher the capital expenditure, the greater the level of corporate leverage. On the other hands, the association of dividend yield with firm size, profitability, leverage, and capital expenditure has the same direction of correlation.

The result of heteroscedasticity testing using the White test can be indicated that in table three regarding test heteroscedasticity, it is showed the F probability value of 0.6837 means that the value is greater than $5 \%$, hence homoscedasticity has occurred. Based on the two tests above this data meets the requirements with classical assumptions and does not occur in autocorrelation.

Table 3. Test of Heteroscedasticity: White

\begin{tabular}{lllr}
\hline \hline F-statistic & 0.795809 & Prob. F (13,298) & 0.6837 \\
Obs*R-squared & 91.591618 & Prob. Chi-Square (13) 0.6107 \\
Scaled explained SS & 150.3754 & Prob. Chi-Square (13) 0.0000
\end{tabular}

Source : (Result of data analysis, 2019)

In the test of autocorrelation using the Breusch-Godfrey test is indicated that in table four the result of test autocorrelation showed $\mathrm{F}$ probability value of 0.000 , which means that the value is greater than 5\% thus, there is an error in autocorrelation between one-year observation and the next year. While the data in this research uses panel data, therefore, the effect of the autocorrelation can be ignored. Thus the test is focused on stationary tests as in the previous section.

Table 4. The Result of Autocorrelation Test

Breusch-Godfrey Serial Correlation LM Test:

\begin{tabular}{llll}
\hline \hline F-statistic & 0.795809 & Prob. F(2,305) & 0.0000 \\
Obs*R-squared & 91.591618 & Prob. Chi-Square(2) & 0.0000 \\
\hline \hline
\end{tabular}

Source : (Result of data analysis, 2019) 
Based on table five descriptive statistics, the highest ROA value was 56.10000 with an average of 11.44033 and a standard deviation of 15.68433. The highest LEV is 71.90000 with an average of 13.03767 and a standard deviation of 21.22415. The highest Firm size is 14.420000 while the average is 11.40567 and the standard deviation is 2.695278. The highest CAPEX is 33.00000 with an average of 1.587833 and a standard deviation of 6.144418. The highest DIV is 4.150000 with an average of 1.685637 and a standard deviation of 1.368009 .

Table 5. Descriptive statistics

\begin{tabular}{lrrrrr}
\hline \hline Mean & 1.685637 & 11.44033 & 1.587833 & 13.03767 & 11.40567 \\
Median & 1.845000 & 6.175000 & 0.215000 & 0.815000 & 12.46500 \\
Maximum & 4.150000 & 56.10000 & 33.00000 & 71.90000 & 14.42000 \\
Minimum & 0.000000 & -5.500000 & 0.010000 & 0.230000 & 6.470000 \\
Std. Dev. & 1.368009 & 15.68433 & 6.144418 & 21.22415 & 2.695278 \\
Skewness & 0.172381 & 1.842995 & 4.733387 & 1.864747 & -0.818671 \\
Kurtosis & 1.683934 & 5.459445 & 24.44094 & 5.434223 & 2.072216 \\
Jarque-Bera & 2.313615 & 24.54424 & 686.6670 & 24.79321 & 4.427086 \\
Probability & 0.314489 & 0.000005 & 0.000000 & 0.000004 & 0.109313 \\
Sum & 50.56910 & 343.2100 & 47.63500 & 391.1300 & 342.1700 \\
Sum Sq. Dev. & 54.27203 & 7133.947 & 1094.862 & 13063.47 & 210.6711 \\
Observations & 30 & 30 & 30 & 30 & 30 \\
\hline Source : Result
\end{tabular}

Source : (Result of data analysis, 2019)

Based on the test of panel regression indicated that in the table six the result of the Tobin Q regression test identified as follows: using a 5\% significance level the effect of independent variables: ROA, capital expenditure, leverage, and dividend yields are considered to have influence, but the effect is not strong on the creation of value of the firm. The overall R2 value is 0.142215 which means it is $14.22 \%$ influenced by ROA, leverage, capital expenditure, and dividend yield while $85.78 \%$ is influenced by other factors. With the adjusted R2 value is relatively small, which is equal to $3.6490 \%$.

The regression equation is as follows:

$\mathrm{Y}=2,807429-0,032302 \mathrm{LEV}+0,071987 \mathrm{ROA}$ - 0,024465 CAPEX + 0,001736 DIV + 0,108622 SIZE

Table 6. The result of the Tobin Q Regression Test

Dependent Variable: Q

Method: EGLS Panel (Cross-section random effects)

Sample: 20142016

\begin{tabular}{lllll} 
Variable & \multicolumn{2}{l}{ Coefficient Std. Error } & t-Statistic & Prob. \\
\hline \hline C & 2.807429 & 3.006309 & 0.933846 & 0.3597 \\
LEV & -0.032302 & 0.006336 & -5.098118 & 0.0000
\end{tabular}


Ekadjaja, Henny, and Ekadjaja: The Characteristics of Users Derivative Company...

\begin{tabular}{lllll} 
ROA & 0.071987 & 0.013697 & 5.255809 & 0.0000 \\
CAPEX & -0.024465 & 0.011951 & -2.047178 & 0.0517 \\
& & & & \\
DIV & 0.001736 & 0.225296 & 0.007707 & 0.9939 \\
SIZE & 0.108622 & 0.205805 & -0.527792 & 0.6025 \\
\hline
\end{tabular}

\begin{tabular}{llll}
\hline \hline & Effects Specification & & \\
& S.D. & Rho \\
\hline \hline Cross-section random & 1.345394 & 0.4987 \\
Idiosyncratic random & 1.349016 & 0.5013 \\
\hline \hline
\end{tabular}

\begin{tabular}{llll}
\hline \hline \multicolumn{4}{l}{ Weighted Statistics } \\
\hline \hline R-squared & 0.142215 & Mean dependent var & 0.969452 \\
Adjusted R-squared & 0.036490 & S.D. dependent var & 1.200133 \\
S.E. of regression & 1.221833 & Sum squared resid & 35.82902 \\
F-statistic & 0.795809 & Durbin-Watson stat & 2.635804 \\
Prob. (F-statistic) & 0.563385 & & \\
\hline \hline
\end{tabular}

\begin{tabular}{llll}
\hline \hline & \multicolumn{3}{l}{ Unweighted Statistics } \\
\hline \hline R-squared & 0.147722 & Mean dependent var & 1.935000 \\
Sum squared residual & 59.62788 & Durbin-Watson stat & 1.583794
\end{tabular}

Source : (Result of data analysis, 2019)

Based on table seven about the sign produced, the result of the research hypothesis test can be obtained as follows:

H1: There is a significant effect of Return on Assets on the value of the firm.

Based on the test result is identified Return on Asset t-value of 5.255809 with a probability of 0.0000 . This result means there is a positive influence on the value of the firm and significant. Thus the first hypothesis is accepted.

$\mathrm{H} 2$ : There is a significant effect of firm size on the value of the firm.

Based on the test result, it is identified firm size t-value of 0.527792 with a probability of 0.0025. This result means there is a positive influence on the value of the firm and significant. Thus the second hypothesis is accepted.

H3: There is a significant effect of leverage on the value of the firm.

Based on the test result, it is identified that the leverage value of $t$ is -5.098118 with a probability of 0.0000 . This result means there is a significant negative effect on the value of the firm. Thus the third hypothesis is accepted.

H4: There is a significant effect of capital expenditure on the value of the firm.

Based on the test result, it is identified that the capital expenditure t-value of -2.047178 with a probability of 0.0517 . This result means there is a negative influence on the value of the firm, but the effect is not significant. Thus the fourth hypothesis is rejected.

H5: There is a significant effect of dividend yield on the value of the firm. 
Based on the test result, it is identified that dividends yield t-value of 0.007707 with a probability of 0.9939 . This result means there is a positive influence on the value of the firm, but the effect is not significant. Thus the fifth hypothesis is rejected.

Table 7. Signs of Produced

\begin{tabular}{llll}
\hline Variable & Symbol & Signs & Decision \\
\hline ROA & ROA & Positive (Significant) & H1: Accepted \\
Firm Size & Size & Positive (Significant) & H2: Accepted \\
Leverage & Lev & Negative (Significant) & H3: Accepted \\
Capital Expenditure & Capex & Positive (Not Significant) & H4: Rejected \\
Dividend Yield & Div & Positive (Not Significant) & H5: Rejected \\
\hline
\end{tabular}

Source : (Result of data analysis, 2019)

(Lau, 2016) and (Obradovich and Gill, 2013) argued that financial markets prefer companies that provide large rewards or profits with high corporate value. Companies that use derivatives tend to have control over the value of the company to benefit the financial market. When the return on assets owned by the company is high, it is the higher the value of the company.

The higher Return on Assets, it is the higher the value of the company. This is due to the high Return on Assets, the shareholders' share earnings will increase so that shareholder welfare increases. The result of the study indicated that Return on Asset has a positive and significant effect. However, the company's profitability (proxied by Return on Assets) increases, the value of the firm directly increases. This is due to the higher profit of a company that tends to make investors buy shares of the company. A large number of investors who buy company shares makes the company's stock price increase. Increasing stock prices directly increases the value of the company, while increasing the welfare of shareholders. Based on the result of the research, it can be concluded that the profitability of derivative user companies (in this research used Return on Asset as a proxy for profitability) can affect company value.

According to (Herrera and Sanchez Gonzalez, 2013), the size of the company is the scale of large and small of the company. In reporting on its financial condition, the company needs to apply a prudent and more transparent system, hence the company has a higher quality of earnings which causes an increase in the value of the company. (Lau, 2016), (Dwi and Khorul, 2014), and (Obradovich and Gill, 2013) argued that the larger companies prefer to use derivatives to control prices with high costs, this can control the value of the company when using derivatives. The larger the company size, the higher the value of the company. The result of the research indicated that the size of the company has a positive and significant influence. So if the company size is increased, the value of the company directly increases. Based on the result of this research it can be concluded that the company size can affect the value of the company.

The higher leverage means that the company utilizes debt in its operational activities, with the expectation of an increase in profitability. With increasing profitability, the value of the company will increase. This is not a rule out the possibility of increasing the company's risk. Companies that have transaction exposures will have debt with foreign exchange, this triggers the risk of exchange rate fluctuations, and thus the increase in debt can have a negative impact on the value of the company. 
(Lau, 2016) argued that the company's capital structure is closely related to the value of the company, because the higher the leverage, the higher the interest expense, the value of the company will decrease after deducting interest and tax expenses. The result of the research indicated that company leverage has a negative and significant influence. Hence, if the company's leverage increases, the company value decreases.

In this research, leverage is proxied by the debt ratio (the ratio of total debt to total assets). With the increase in corporate debt (indicated by leverage) tends to reduce the value of the company due to investor fear of the solvency of the company so investors are hesitant to buy shares of the company. The price of the company's shares does not rise and even tended to decrease which resulted in a decrease in the value of the company. Based on the result of the research it can be concluded that company leverage can affect the value of the company.

Increasing capital expenditure causes a decrease in corporate profits. (Dewa et al., 2017) explained that capital expenditure or capital expenditure is expenditure to improve operating efficiency, increase productive capacity, or extend the useful life of fixed assets are generally quite large (material) and the emergence of unpredictable (sudden). The ratio of capital expenditure to sales is used to measure CAPEX which is a proxy for investment opportunities. (Pascual, 2013) argued that companies that do hedging are preferred because they have investment opportunities.

(Litt, 2013) stated that the opportunity to invest in a company is indicated by the existence of capital expenditure where the company that does the hedge is more willing to invest in fixed assets. The higher the investment made in capital expenditure, the higher the value of the company. The result of the research indicated that the company's capital expenditure has a negative but not significant effect. Hence, the company's capital expenditure increases, the company's value decreases.

Increasing capital expenditure (capital expenditure/ adding new assets) result in the possibility of additional costs so that the company's profits decrease, as a result, the company's value will decrease. But based on the result of the research the effect of capital expenditure on firm value is not significant, so it can be concluded that capital expenditure does not have an influence on increasing the value of the company.

The company distributes dividends to shareholders with the aim of making investors interested in the company's shares while increasing the income of shareholders. According to (Guan et al., 2018) the dividends are compensation received by shareholders, in addition to capital gains. (Mihai Yiannaki, 2013) argued that if the company does a hedge or derivative for a project, this is because the company has limited access to financial markets. Therefore, companies that pay high dividends will reduce the value of the company due to the large dividends paid to ordinary shareholders in that year.

The result of the research indicated that the company's yield dividends have a positive but not significant effect. However, the company's dividends increase, the company's value also increases. This is in accordance with (Hoffmann's, 2014), where the value of companies tends to increase if the company increases its dividends. In general, if a company often provides dividends, investors will be interested in buying shares in the company. Hence, it is in line with the law of demand, if the demand for shares increases, then the share price will increase directly. Increasing the company's share price will indirectly increase the value of the company. 
Based on the relationship between the variables above, it can be concluded that the profitability proxied by ROA showed the level of net profit that can be achieved by the company. Moreover, the shareholders are eligible to get a share of the profits after deducting interest and taxes, this is reflected in the distribution of dividends by the company. The advantage that is shared by shareholders is profit after interest and tax.

High ROA also showed the company's ability to provide dividends to its shareholders. As a contribution, if a company provides dividends to its shareholders it can improve the welfare and ability of shareholders in determining company policy. In addition, the company's ability to pay dividends makes savings on the company's capital costs and increases shareholders' ownership. Therefore profitability is an important consideration for investors in investment decisions. Partially from the five variables (ROA, LEV, CAPEX, SIZE, and DIV) together, which has a significant influence on the value of the firm is Return on Assets, firm size, and leverage.

\section{CONCLUSION}

Based on linear testing of companies listed on the Sharia Stock Index on the Indonesian Stock Exchange from 2014-2016 the following result was identified: Companies that do derivatives for three consecutive years were ten companies. The test showed that the variable Return on Assets and firm size has a significant positive effect on the value of the firm that the derivative user uses. While capital expenditure and dividend yield showed that there is no significant positive effect on firm value and the leverage variable showed a significant negative effect on firm value.

Managerial implications of the result of the research, such as increasing profits (in this case indicated by Return on Assets), company size, and dividend yield tend to increase the value of the company. Conversely, when debt (leverage) increased capital expenditure, tend to reduce the value of the company. This is probably due to the fear of investors to invest in companies that have large debts because of the possibility of the company's inability in financial matters. Therefore Return on Assets, firm size, and dividend yield can be used as the material for consideration by investors in making investment decisions.

The limitation of this research is first, there are not many research samples where the data is only taken from companies listed on the Islamic Stock Index on the Stock Exchange from 2014-2016 on the condition that the company uses derivative instruments. Secondly, it only uses secondary data in the form of the company's annual financial report data.

The suggestions for the development of further research are first, the addition of research samples of derivative user companies on the Indonesian Stock Exchange, for example, development through the addition of research periods and company categories due to the lack of derivative user companies. Firstly, it is expected that the addition of samples will increase the value of the coefficient of determination (R2). The increase in the value of the coefficient of determination (R2) reflects the magnitude of the influence of the independent variable on firm value (dependent variable). Secondly, addition of the independent variables can be adjusted to the development of independent variables that refer to a number of important decisions in financial management, such as: funding decisions, investments, dividends, and considering the company's fundamental conditions 
such as: business risk and company growth towards firm value as the dependent variable. Thirdly, it is using data processing tools such as AMOS and SEM.

\section{REFERENCE}

Aaj, j., Satriawan, H. B., dan Agustina, L. (2016). Determinan Harga Saham Dengan Nilai Perusahaan Sebagai Variabel Intervening. Accounting Analysis Journal, 5(2), 113121.

Arnold, M. M., Rathgeber, A. W., dan Stockl, S. (2014). Determinants of corporate hedging: A (statistical) meta-analysis. The Quarterly Review of Economics and Finance, 54(4), 443-458.

Bartram, S. M., Brown, P., How, J. C., dan Verhoeven, P. (2012). Agency Conflicts and Corporate Payout Policies: A Global Study. https://papers.ssrn.com/sol3/papers.cfm?abstract_id=1068281.

Bolek, M. (2014). Return On Current Assets, Working Capital And Required Rate of equity. e-Finance, 10(2), 1-10.

Boumosleh, A. S., dan Raad, E. (2012). Market Reaction to Capital Expenditures of Powerful CEOs. International Journal of Financial Services Management, 5(4), 356-368. DOI: 2012.048850.

Cassidy, N., Doherty, E., Dan Gill, T. (2012). Forecasting Business Investment using the Capital expenditure survey.

Du, J., dan Girma, S. (2012). Firm Size, Source of Finance, and Growth - Evidence from China. International Journal of The Economics of Business, 19(3), 397-419.

García-Feijoo, L., Kaprielyan, M., Madura, J., \& Viale, A. M. (2015). Target valuation complexity and takeover premiums. International Journal of Banking, Accounting and Finance 6(2), 151. DOI: 2015.077033.

Guan, J. X., Li, O. Z., and Ma, J. (2018). Managerial ability and the shareholder tax sensitivity of dividends. Journal of Financial and Quantitative Analysis, 53(01), 335-364.

Herrera, L., dan Sanchez Gonzalez, G. (2013). Firm size and innovation policy. International. Small Business Journal, 31(2), 137-155. DOI :0266242611405553.

Hoffmann, P. S. (2014). Internal corporate governance mechanisms as drivers of firm value: panel data evidence for Chilean firms. Review of Managerial Science, 8(4), 575-604 .

Kartini, K., dan Hasridha, R. A. (2014). Kebijakan Hedging dengan Derivatif Valuta Asing pada Perusahaan Go Public di Indonesia Periode 2009-2012.

Lau, C. K. (2016). How corporate derivatives use impact firm performance. Pacific-basin Finance Journal, Vol. 40, 102-114.

Litt, B. A. (2013). Why Do Firms Invest in Capital Expenditures? Evidence from Environmental Activities. International journal of business and social science, 4(8), 51.

McCown, J. R., and Shaw, R. (2017). Investment Potential and Risk Hedging Characteristics of Platinum Group Metals. The Quarterly Review of Economics and Finance, 63, 328-337.

Mihai-Yiannaki, S. (2013). To hedge or not to hedge during the financial crisis: a case study. Global Business and Economics Review, 15, 210-232. DOI: 2013.053070. 
Nandita, A. (2018). Pengaruh Profitabilitas, Leverage, Size, dan Kebijakan Dividen Terhadap Nilai Perusahaan.

Nurqinanty, P. (2018). Pengaruh Struktur Modal, Profitabilitas, Dan Ukuran Perusahaan Terhadap Nilai Perusahaan.

Pascual, J. L. (2013). The Investment in Hedge Funds as an Alternative Investment. https: //intechopen.com/books/engineering-management/the-investment-in-hedge-fundsas-an-alternative-investment.

Putro, S. H., dan Chabachib, M. (2012). Analisis Faktor Yang Mempengaruhi Penggunaan Instrumen Derivatif Sebagai Pengambilan Keputusan Hedging (Studi Kasus Pada Perusahaan Automotive and Allied Products Yang Terdaftar Di BEI Periode 20062010). http://eprints.undip.ac.id/35891.

Servaes, H., dan Tamayo, A. (2013). The Impact of Corporate Social Responsibility on Firm Value: The Role of Customer Awareness. Management Science, 59(5), 10451061.

Setiawan, D., dan Kartika, A. (2013). Pengaruh Insider Ownership, Struktur Modal, Kebijakan Hutang dan Dividen Terhadap Nilai Perusahaan. Students' Journal of Accounting and Banking, 2(1).

Setiawan, T. (2017). Pengaruh Kebijakan Deviden terhadap Laba Satu Tahun ke Depan. http://trijurnal.lemlit.trisakti.ac.id/index.php/mraai/article/view/1641.

Sprcic, D. M., dan Sevic, Z. (2012). Determinants of corporate hedging decision: Evidence from Croatian and Slovenian companies. Research in International Business and Finance, 26(1), 1-25.

Tai, V. W., Lai, Y.-H., an Lin, L. (2014). Local institutional shareholders and corporate hedging policies. The North American Journal of Economics and Finance, 28, 287312.

Watson, R. N. (2013). Financial Leverage and Corporate Governance. http://oxfordhandbooks.com/view/10.1093/oxfordhb/9780199642007.001.0001/oxfo rdhb-9780199642007-e-12

William, A. P. (2015). Price Book Value \& Tobin's Q: Measurement Which One is Better for Corporate Governance? European Journal of Business and Management, 7(27), 74-79.

Zeng, T. (2014). Derivative financial instruments, tax aggressiveness, and firm market value. Journal of Financial Economic Policy, 6(4), 376-390. 